\title{
Epilogue
}

\section{Institutionalising mobilities research: networks, regions, futures}

\section{Networks}

As a style of thought that helps to make legible the richness and complexity of contemporary life, mobilities research provides hugely valuable political, ethical and practical responses to some of our most pressing challenges. From the outset, the new mobilities paradigm has been concerned with tracing the relationships of different sorts of mobility and how they are entangled. John Urry (2002) provides a useful way of systematising different sorts of mobilities. He invites us to think about the physical movement of objects; the virtual travel of digital communication; the corporeal movement of people and the imaginative travel of imagery and ideas.

The papers in this special issue speak to this diversity well, and allude to different configurations of Urry's schematisation. Adams-Hutcheson investigates the mobilities of academic projects and how their momentary stabilisation in ethics contracts betrays the shape-shifting contingency of unfolding research situations. Officer and Kearns look at the mobilities of commuting bodies as they bump and jostle through their everyday railway commutes in Auckland. Henry and Scott explore the mobility of numbers in terms of how they can be transformed to advocate for sustainable cycling initiatives. Roche speaks to the mobilities of infrastructures themselves, to show how roads are not inert objects but materials that are always in-formation through maintenance and repair. Tsai and Collins explore the mobilities of Taiwanese labouring bodies as they navigate the freedoms and constraints of working holidays in New Zealand.

The first of these papers, in particular, provides a fascinating reflection on the mobility of ideas. Given that the mobilities paradigm has reached a certain maturity since it emerged fifteen years ago or so,

This is the author manuscript accepted for publication and has undergone full peer review but has not been through the copyediting, typesetting, pagination and proofreading process, which may lead to differences between this version and the Version of Record. Please cite this article as doi: $10.1111 /$ nzg.12167 
I find it curious that imaginative travel—or the mobility of ideas — has often, to my mind, received considerably less attention than the other types in Urry's schema. There might be many reasons for this. Ontologically, the imaginative dimensions of life are perhaps a little trickier to grapple with, methodologically, than the movements of entities that have a less-flighty existence. But I think that this curious oversight is problematic because it overlooks how ideas are a constitutive and powerful force in the world, as Adams-Hutcheson shows.

The imaginative mobilities of ideas are not free-floating things. Ideas can take geographically distinctive spatiotemporal forms. One way of imagining this is through the metaphors of flows and hubs. As mobilities researchers have consistently pointed out, anchoring hubs are vital to the sustenance and development of networked flows (Crang, 2002). However, whereas transportation hubs such as airports have been the focus of much mobilities research, the hubs that anchor the mobility of ideas can turn our attention to knowledge institutions which include universities, disciplines, and professional organisations.

Where Euro-American institutions have given rise to some of the most important hubs for mobilities research, what we can witness in Aotearoa New Zealand over the past decade, is the formation of a new and important hub through the Mobilities Network for Aotearoa New Zealand. The network's annual symposium is itself a mobile entity, moving to a different university each year, and hosted by a different discipline that gives each annual event a unique tone, raising new questions about the relationship of mobilities research to other disciplinary perspectives.

One of the benefits of a mobile conference is that whilst there is a core collective of mobilities researchers who travel and contribute to each symposium, every event attracts a different local contingent which differently inflects the conversations that take place. ${ }^{1}$ There is much to be gained from this plurality as new ideas for mobilities research emerge, new projects take shape, and new friendships form.

\footnotetext{
${ }^{1}$ I have been lucky enough to attend three of the symposia. I am grateful for the invitation to present at the second symposium in Palmerston North in 2011 which explored relationships of mobilities and neighbourhoods (see Bissell, 2013).
} 
Adding international voices into the symposium debate is a key part of the annual symposium, which takes advantage of videoconferencing technologies and time-zone differences, with dinner-time overseas tele-keynotes made extra-convivial with food and drinks.

Whilst one of the most valuable dimensions of mobilities research is its interdisciplinary nature (see, for instance, Adey et al., 2014), mobilities research has been particularly transformative for geography. In that regard, it is exciting to witness the more recent formation of the New Zealand Geographical Society Mobilities in Geography Study Group. The success and longevity of the Mobilities Network for Aotearoa New Zealand and the formation of the new geography study group is testament not only to the hard work that several people have put into driving it, ${ }^{2}$ but also to the breadth of interesting mobilities research that is emerging in this part of the world.

\section{Regions}

There is a uniqueness to the way that mobilities research takes place in New Zealand. Part of this is about how the Mobilities Network for Aotearoa New Zealand operates, especially through its annual 'mobile' symposium, and the singular passions and dispositions that the academics involved in championing mobilities research in New Zealand bring to this. But another part of its uniqueness is about the distinctiveness of the research itself and the issues that have become prominent. This is particularly evident through the papers in this special issue.

Adams-Hutcheson zooms in on two situations that are distinctive to this part of the world, raising important questions about ethics in mobilities research. Whilst sharemilking is a quintessentially New Zealand agricultural practice that creates its own unique enablements and constraints, how family and social networks are transformed by the geological forces of earthquakes takes on a distinctive hue in New Zealand.

\footnotetext{
${ }^{2}$ Martha Bell, Maria Borovnik, Tara Duncan and Gail Adams-Hutcheson have been key advocates for mobilities research in New Zealand.
} 
Officer and Collins discuss the significance of bodily encounters on Auckland's suburban trains. Their autoethnographic account highlights place-based rituals and rites of passage that are particular to this city. Henry and Scott alert us to how local governments in New Zealand work with statistics to advocate for sustainable transport which raises important questions about the mobilities of data. Whilst this is an issue that many jurisdictions over the world grapple with, they illuminate how the policy context in New Zealand has a local specificity that inflects how data performs. Roche provides a detailed account of the changing form of roads in part of the South Island of New Zealand which raises key questions about history and infrastructure in mobilities research. The materials and processes that he describes evoke a specificity to this part of the South Island, such as the challenges of taming gorse hedges mixed with the labours of shingling surfaces. Tsai and Collins examine a distinctive mobile ritual in this part of the world that raises key questions about politics in mobilities research. Backgrounded against the more researched 'OE' (Overseas Experience), very much a New Zealand practice, they trace some of the tensions that emerge through different cultural conceptions and expectations of Taiwanese youth whilst on working holidays that take place in New Zealand itself.

The formalisation of mobilities research in New Zealand provides an exciting opportunity to draw out this specificity further, inspiring new research trajectories and ways of theorising that might be different from those that are emerging in European and North-American contexts. Sociologist Raewyn Connell's (2007) Southern Theory is a powerful call to develop social theories that include voices from outside the dominant European and North American metropoles - the historically-dominant sites of academic knowledge production. As Connell points out, this doesn't mean retreating into a new form of parochialism (which would be reactive and dangerous). Neither does it mean a renewed enthusiasm for area studies, as debates on the idea of scale within geography have shown that such nested hierarchies are problematic (see Marston et al., 2005). What it does mean is being more attentive to the specific configuration of forces that are shaping life here, and the different questions and problems that these forces generate. For Connell, this certainly means being more attentive to the different ways of knowing that different indigenous voices 
present, and indeed, the challenge of being more alert to the situatedness and diversity of all voices. But it also means being more attentive to the non-human forces of landscapes and places that are very specific to here.

Practically, in addition to the topics covered in the papers in this special issue, issues such as environmental destruction; mobile working practices; mobile encounters with landscapes, have a real specificity to New Zealand that theories from Euro-American contexts might not adequately be able to do justice to. So, whilst mobilities research has its genesis in a network of European knowledge institutions, it is an exciting challenge to explore how our situatedness in this part of the world creates a host of opportunities for becoming more attentive to the unique forces that are operating here; and from this, develop novel theories that are faithful to this part of the world, rather than deferent to Euro-American convention.

\section{Futures}

The business of speculating on 'mobility futures' has become an important dimension of EuroAmerican mobilities research. From an important practical perspective, this is perhaps not surprising given the pressing imperatives to reduce carbon emissions by moving about differently. But turning to the future of the mobility of ideas, I believe that we are at an exciting moment to consider how we might want our mobility futures to look.

Chiefly inspired by the New Zealand Mobilities Network, this year, a group of us in Australia are launching AusMob, the Australian Mobilities research network. This presents some exciting potentials for intensify mobilities research conversations across the Tasman Sea. Given that mobilities research is strong and getting even stronger in both New Zealand and Australia, the question then is: how might we build on these foundations and identify more opportunities for collaboration and dialogue, if that is an aim that we share? 
Comparative research is one avenue. However, and potentially even more excitingly, mobilities researchers are clearly well placed to develop projects that are attuned to flows. We could use these skills to develop research on the different sorts of flows between New Zealand and Australia. Put simply, the Trans-Tasman relationship could be a very significant site of mobilities research in and of itself. Think here about the Trans-Tasman travel arrangement that enables the unimpeded movement of most New Zealand and Australian nationals between the two countries. To illustrate, over six million trips are made annually by air between the two countries on over 40 thousand flights. There are currently over half a million New Zealand-born people who live in Australia and about 62,700 Australian-born people who live in New Zealand (ABS, 2010; Statistics NZ, 2013). Economically, the flows of finance between the two countries is hugely significant. Of course this involves tourism, but it also involves workforce migration of various sorts which have become a politically-charged issue on both sides of the Tasman. Intensifying the mobility of ideas across the Tasman through our respective institutions could lead to exciting future collaborations on these topics and more.

\section{Institutions}

In light of the recent founding of the New Zealand Geographical Society Mobilities in Geography Study Group, I will conclude this epilogue with a brief note on the power of institutions. Whilst geographers inspired by Foucault's work on biopolitics have often been quick to point to the repressive or quietly controlling dimensions of certain institutions, Deleuze's (2004) short essay Instinct and Institution gives us cause to reflect on institutions from a rather different angle, affirming, as he does, their more productive dimensions.

The point Deleuze makes is that whilst we often think of institutions as a primary building block for controlling society and keeping change in check, institutions are actually secondary to the 
creative tendencies that exist for something. His point is that tendencies find their satisfaction in institutions, which transforms those tendencies further. This is a reversal of sorts from a more conventional way of thinking about institutions. It indicates how institutions are powerful, not because they are where power is wielded, but rather because they can assist in satisfying and further catalysing creative tendencies. An example that Deleuze gives is how sexuality understood as a creative tendency can find its satisfaction in marriage, an institution. For us, to draw a parallel, we might suggest that the creative tendencies that are our passions for mobilities research can find their satisfaction in institutions such as the New Zealand Geographical Society Mobilities in Geography Study Group, catalysing and transforming those tendencies further.

So to finish, it is worthwhile reflecting on the affirmative tendencies our study groups and networks are satisfying. Amongst them, I would venture, are intellectual tendencies: to think differently, more boldly, more adventurously. But what I've learned from being involved in the Mobilities Network for Aotearoa New Zealand is that these are also tendencies of generosity, care, and friendship. For that reason, I think that we have much to cherish about our new and evolving institutions.

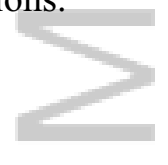

\section{References}

ABS (2010). 4102.0 - Australian Social Trends, Sep 2010. Australian Bureau of Statistics, Canberra.

Adey P, Bissell D, Hannam K, Merriman P, Sheller M (2014). The Routledge Handbook of Mobilities. Routledge, London.

Bissell D (2013). Pointless mobilities: rethinking proximity through the loops of neighbourhood. Mobilities 8, 349-67. 
Crang M (2002). Between places: producing hubs, flows, and networks. Environment and Planning A 34, $569-74$.

Connell R (2007) Southern Theory. Allen and Unwin, Crows Nest, NSW.

Deleuze G (2004). Desert Islands and Other Texts, 1953-1974. Semiotext(e), Los Angeles, CA.

Marston SA, Jones JP, Woodward K (2005). Human geography without scale. Transactions of the Institute of British Geographers 30, 416-432.

Urry J (2002). Mobility and proximity. Sociology 36, 255-74.

Statistics NZ (2013). 2013 Census QuickStats about culture and identity.

http://www.stats.govt.nz/Census/2013-census/profile-and-summary-reports/quickstats-cultureidentity.aspx, Accessed 16 May 2017.

This article is protected by copyright. All rights reserved. 


\section{University Library}

\section{- M M I E E R VA A gateway to Melbourne's research publications}

Minerva Access is the Institutional Repository of The University of Melbourne

Author/s:

Bissell, D

Title:

Institutionalising mobilities research: Networks, regions, futures

Date:

2017-08-01

Citation:

Bissell, D. (2017). Institutionalising mobilities research: Networks, regions, futures. NEW ZEALAND GEOGRAPHER, 73 (2), pp.141-144. https://doi.org/10.1111/nzg.12167.

Persistent Link:

http://hdl.handle.net/11343/293259 